NBER WORKING PAPER SERIES

\title{
THE FINANCIAL CRISIS AND THE POLICY RESPONSES: AN EMPIRICAL ANALYSIS OF WHAT WENT WRONG
}

\author{
John B. Taylor \\ Working Paper 14631 \\ http://www.nber.org/papers/w14631 \\ NATIONAL BUREAU OF ECONOMIC RESEARCH \\ 1050 Massachusetts Avenue \\ Cambridge, MA 02138 \\ January 2009
}

I am grateful to John Cogan, Angelo Melino, John Murray, George Shultz and participants in the Global Markets Working Group for helpful comments and suggestions. The views expressed herein are those of the author(s) and do not necessarily reflect the views of the National Bureau of Economic Research.

NBER working papers are circulated for discussion and comment purposes. They have not been peerreviewed or been subject to the review by the NBER Board of Directors that accompanies official NBER publications.

(C) 2009 by John B. Taylor. All rights reserved. Short sections of text, not to exceed two paragraphs, may be quoted without explicit permission provided that full credit, including $\odot$ notice, is given to the source. 
The Financial Crisis and the Policy Responses: An Empirical Analysis of What Went Wrong John B. Taylor

NBER Working Paper No. 14631

January 2009

JEL No. E0,G01

\section{$\underline{\text { ABSTRACT }}$}

This paper is an empirical investigation of the role of government actions and interventions in the financial crisis that flared up in August 2007. It integrates and summarizes several ongoing empirical research projects with the aim of learning from past policy. The evidence is presented in a series of charts which are backed up by statistical analysis in these research projects.

John B. Taylor

Herbert Hoover Memorial Building

Stanford University

Stanford, CA 94305-6010

and NBER

John.Taylor@stanford.edu 


\title{
The Financial Crisis and the Policy Responses: An Empirical Analysis of What Went Wrong
}

\author{
John B. Taylor \\ November 2008
}

What caused the financial crisis? What prolonged it? Why did it worsen so dramatically more than a year after it began? Rarely in economics is there a single answer to such questions, but the empirical research I present in this paper strongly suggests that specific government actions and interventions should be first on the list of answers to all three. I focus on the period from the start of the crisis through October 2008 when market conditions deteriorated precipitously and rapidly. I draw on research papers, speeches at central banks, and congressional testimony I have given on the crisis during the past two years. ${ }^{1}$

This paper is based on the keynote lecture delivered in Ottawa on November 14 at a conference in honor of David Dodge, former Governor of the Bank of Canada. Following an approach to policy advocated by David Dodge throughout his distinguished career in public service, I try to use empirical evidence to the maximum extent possible and explain the analysis in the simplest possible terms, including by using a series of illustrative graphs.

\section{What Caused the Financial Crisis?}

The classic explanation of financial crises, going back hundreds of years, is that they are caused by excesses — frequently monetary excesses — which lead to a boom and an inevitable bust. In the recent crisis we had a housing boom and bust which in turn led to financial turmoil in

\footnotetext{
${ }^{1}$ I refer to this research in this paper using the bracketed numbers in the section "Summary of Research Projects" at the end of the paper.
} 
the United States and other countries. I begin by showing that monetary excesses were the main cause of that boom and the resulting bust.

\subsection{Loose Fitting Monetary Policy}

Figure 1 was published in The Economist magazine in October 2007 as a simple way to illustrate the story of monetary excesses. The figure is based on a paper [1] that I presented at the annual Jackson Hole conference in August 2007. It examines Federal Reserve policy decisions_-in terms of the federal funds interest rate—from 2000 to 2006.

The line that dips down to one percent in 2003, stays there into 2004, and then rises steadily until 2006 shows the actual interest rate decisions of the Federal Reserve. The other line shows what the interest rate would have been if the Fed had followed the type of policy that it had followed fairly regularly during the previous 20 year period of good economic performance. The Economist labels that line the Taylor rule because it is a smoothed version of the interest rate one gets by plugging actual inflation and GDP into a policy rule that I proposed in $1992 .^{2}$ But the important point is that this line shows what the interest rate would have been if the Fed had followed the kind of policy that had worked well during the historical experience of the Great Moderation that began in the early 1980s.

\footnotetext{
${ }^{2}$ When he was President of the Federal Reserve Bank of St. Louis, William Poole presented a similar chart covering a longer period and without the smoothing in "Understanding the Fed," Federal Reserve Bank of St. Louis, Review, January/February, 2007, Vol. 89. No. 1, pp. 3-14
} 


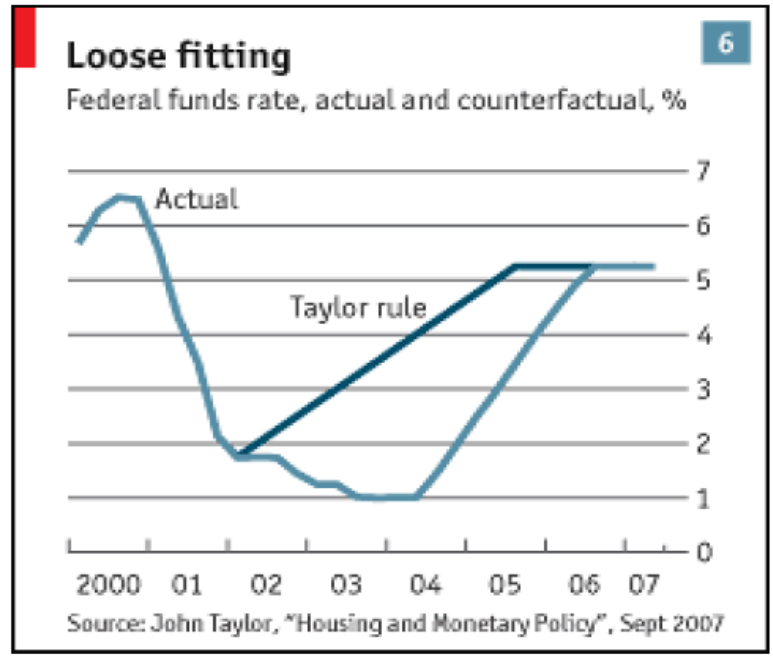

\section{Figure 1. Chart from The Economist, October 18, 2007}

Figure 1 shows that the actual interest rate decisions fell well below what historical experience would suggest policy should be. It thus provides an empirical measure that monetary policy was too easy during this period, or too "loose fitting" as The Economist puts it. This was an unusually big deviation from the Taylor rule. There was no greater or more persistent deviation of actual Fed policy since the turbulent days of the 1970s. So there is clearly evidence that there were monetary excesses during the period leading up to the housing boom.

The unusually low interest rates decisions were, of course, made with careful consideration by monetary policymakers. One can interpret them as purposeful deviations from the "regular" interest rate settings based on the usual macroeconomic variables. The Fed used transparent language to describe the decisions, saying, for example, that interest rates would be low for “a considerable period” and that they would rise slowly at a "measured pace,” which were ways of clarifying that the decisions were deviations from the rule in some sense. These actions were thus effectively discretionary government interventions in that they deviated from 
the regular way of conducting policy in order to address a specific problem, in particular a fear of deflation as had occurred in Japan in the 1990s.

\subsection{The Counterfactual: No Boom, No Bust}

In presenting this chart to the central bankers meeting in Jackson Hole in August 2007 I argued that this extra easy policy was responsible for accelerating the housing boom and thereby ultimately leading to the housing bust. To support such an argument empirically I provided statistical evidence that the interest rate deviation shown in Figure 1 could plausibly bring about

a housing boom. I did this by using regression techniques to estimate a model of the empirical relationship between the interest rate and housing starts, and I then simulated that model to see what would have happened in the counterfactual event that policy had followed the rule shown in Figure 1. In this way an empirical proof was provided that monetary policy was a key cause of the boom and hence the bust and the crisis.

Figure 2 summarizes the results of this empirical approach. It is a picture of housing starts in the United States during the same period as Figure 1; it is drawn from that same 2007 Jackson Hole paper [1]. The jagged line shows actual housing starts in thousands of units. Both the housing boom and the housing bust are very clear in this picture. 


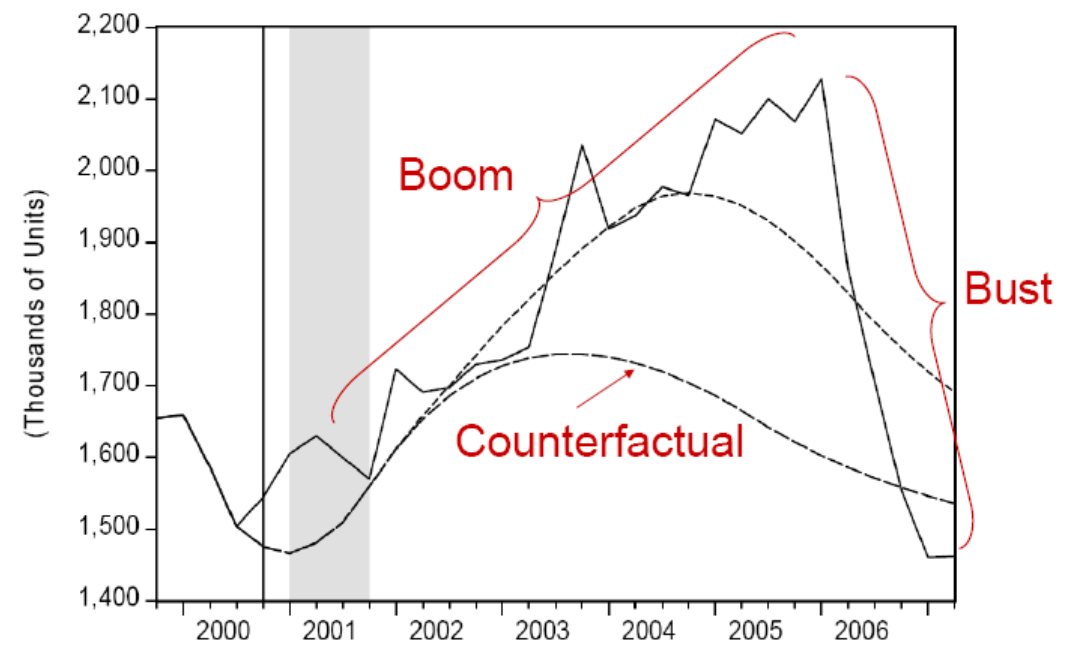

Figure 2. The Boom-Bust in Housing Starts Compared With the Counterfactual. (The line with shorter dashes shows model simulations with the actual interest rate.)

The line labeled “counterfactual” in Figure 2 is what a statistically estimated model of housing starts suggests would have happened had interest rates followed along the rule in Figure 1; clearly there would have not been such a big housing boom and bust. Hence, Figure 2 provides empirical evidence that the unusually low interest rate policy was a factor in the housing boom. One can challenge this conclusion, of course, by challenging the model, but an advantage of using a model and an empirical counterfactual is that one has a formal framework for debating the issue.

Not shown in Figure 2 is the associated boom and bust in housing prices in the United States. The boom-bust was evident throughout most of the country, but was worse in California, Florida, Arizona and Nevada. The only exceptions were in states like Texas and Michigan where local factors offset the monetary excess stressed here. 
Though the housing boom was the most noticeable effect of the monetary excesses, they also could be seen in more gradually rising overall prices: CPI inflation, for example, averaged 3.2 percent at an annual rate during the past five years, well above the 2 percent target suggested by many policy makers and implicit in the policy rule in Figure 1. It is always difficult to predict the exact initial impacts of monetary shocks, but housing was also a volatile part of GDP in the 1970s another period of monetary instability before the onset of the Great Moderation. The monetary policy followed during the Great Moderation had the advantages of keeping both the overall economy stable and the inflation rate low.

\subsection{Competing Explanations: A Global Saving Glut}

Some argue that the low interest rates in 2002-2004 were caused by global factors beyond the control of the monetary authorities. If so, then the interest rate decisions by the monetary authorities were not the major factor causing the boom. This explanation is potentially appealing because long term interest rates remained low for a while even after the short-term federal funds rate started increasing. This alternative explanation focuses on global saving. It argues that there was an excess of world saving — a global saving glut—which pushed interest rates down in the United States and other countries.

The main problem with this explanation is that there is actually no evidence for a global saving glut. On the contrary, as Figure 3 shows in very simple terms, there seems to be a saving shortage. This figure, which was produced by staff at the International Monetary Fund in 2005, shows that the global saving rate—world saving as a fraction of world GDP—was very low in the 2002-2004 period especially when compared with the 1970s and 1980s. So this alternative explanation does not stand up to empirical testing using data that have long been available. 


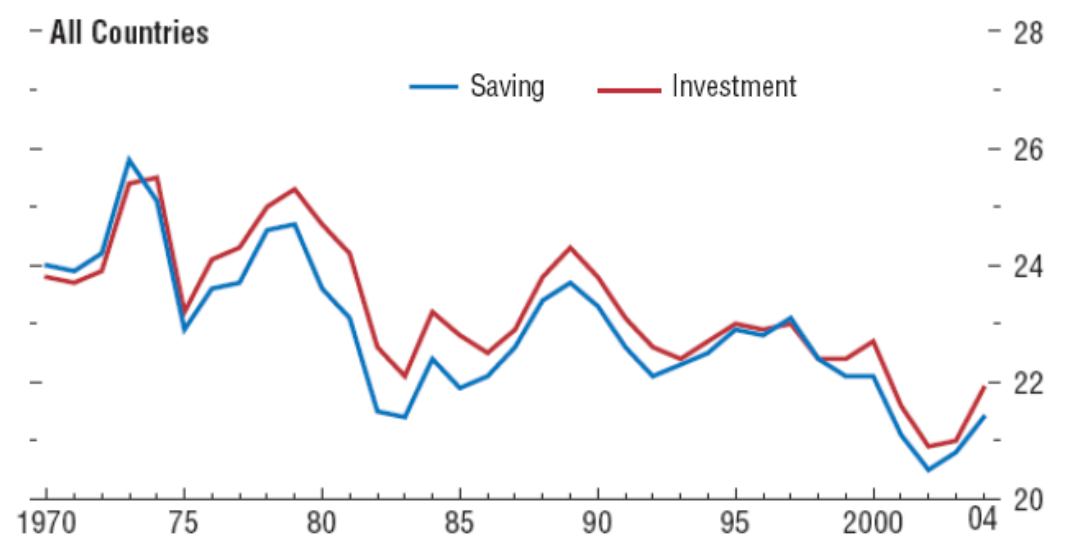

Figure 3. Global Saving and Investment as a Share of World GDP Source: World Economic Outlook, IMF Sept 2005, Chapter 2, p. 92,

To be sure, there was a gap of saving over investment in the world outside the United States during 2002-2004, and this may be the source of the term "saving glut.” But the United States was saving less than it was investing during this period; it was running a current account deficit which implies that saving was less then investment. Thus the positive saving gap outside the United States was offset by an equal sized negative saving gap in the United States. No extra impact on world interest rates would be expected. As implied by simple global accounting, there is no global gap between saving and investment.

\subsection{Monetary Policy in Other Countries: Central Banks Looking at Each Other?}

Nevertheless there are possible global connections to keep track of when assessing the root cause of the crisis. Most important is the evidence that interest rates at several other central banks also deviated from what historical regularities, as described by a Taylor rule, would predict. Even more striking is that housing booms were largest where the deviations from the 
rule were largest. ${ }^{3}$ For example, within Europe the deviations from the Taylor rule vary in size because inflation and output data vary from country to country. The country with the largest deviation from the rule was Spain, and it had the biggest housing boom, measured by the change in housing investment as a share of GDP. The country with the smallest deviation was Austria; it had the smallest change in housing investment as a share of GDP. The very close correlation is shown in Figure 4 which plots the sum of deviations from the policy rule on the horizontal axis and the change in housing investment as a share of GDP on the vertical axis.

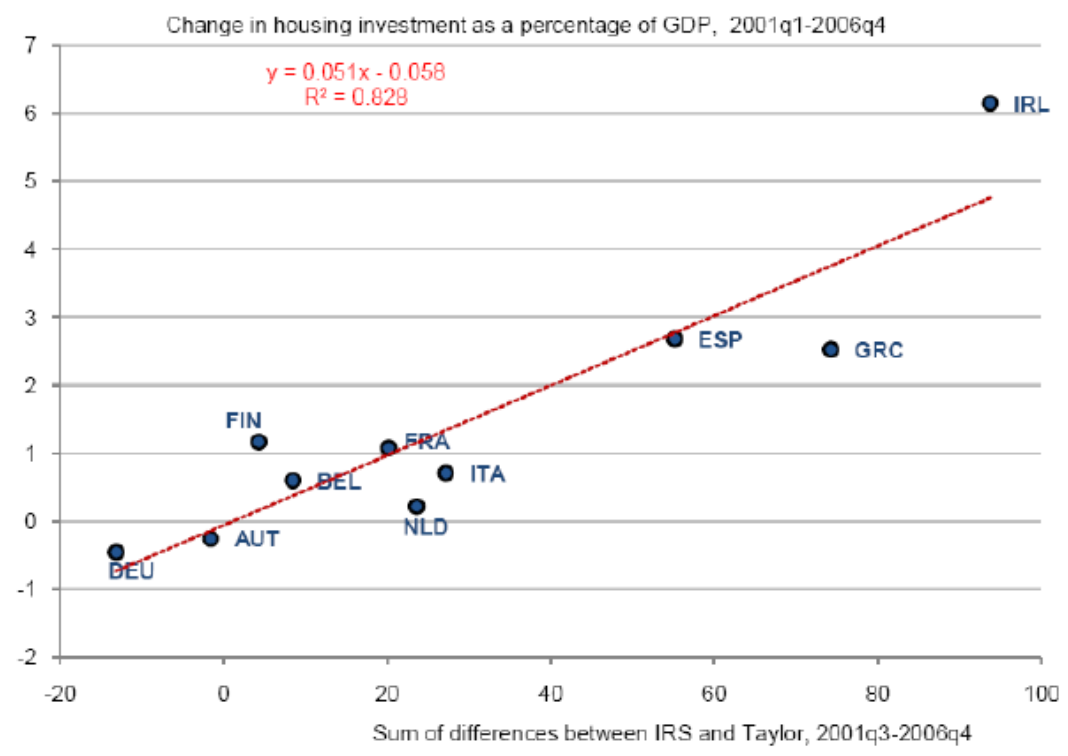

Figure 4. Housing Investment Versus Deviations From the Taylor Rule in Europe (Source: See footnote 3.)

An important question, with implications for reform of the international financial system, is whether these low interest rates at other central banks were influenced by the decisions in the

${ }^{3}$ R. Ahrend, B. Cournède and R. Price provide a fascinating analysis of the experiences in OECD countries during this period in their paper "Monetary Policy, Market Excesses and Financial Turmoil", OECD Economics Department Working Papers, No. 597, March 2008. They show that the deviations from the Taylor rule explain a large fraction of the cross-country variation in housing booms in OECD countries. 
United States or represented an interaction among central banks that caused global short interest rates to be lower than they otherwise would have been. To test this hypothesis, I examined the decisions at the European Central Bank in a paper [2] for a talk in Europe in June 2007. I studied the deviations (or the residuals) of the ECB interest rate decisions from the same type of policy rule used in Figure 1, but using Euro zone inflation and GDP data. The interest rate set by the ECB was also below the rule; in other words there were negative residuals. To determine whether those residuals were influenced by the Federal Reserve's interest rate decisions, I ran a regression of them during 2000-2006 on the federal funds rate shown in Figure1. I found that the estimated coefficient was .21 and that it was statistically significant.

Figure 5 gives a visual sense of how much of the ECB interest rate decisions could be explained by the influence of the Fed's interest rate decisions. It appears that a good fraction can be explained in this way. The jagged looking line in Figure 5 shows the deviations of the actual interest rates set by the ECB from the policy rule. (I have not smoothed out the high frequency jagged movements as in Figure 1). By this measure, the ECB interest rate was as much as two percentage points too low during this period. The smoother looking line shows that a good fraction of the deviation can be "explained" by the federal funds rate in the United States.

The reasons for this connection are not clear from this statistical analysis, and are a fruitful subject for future research in my view. Indeed it is difficult to distinguish statistically between the ECB following the Fed and the Fed following the ECB; similar regressions show that there is connection the other way as well. Concerns about the exchange rate, or the influence of the exchange rate on inflation, could generate such a relationship. So could third factors such as changes in the global real interest rate. 


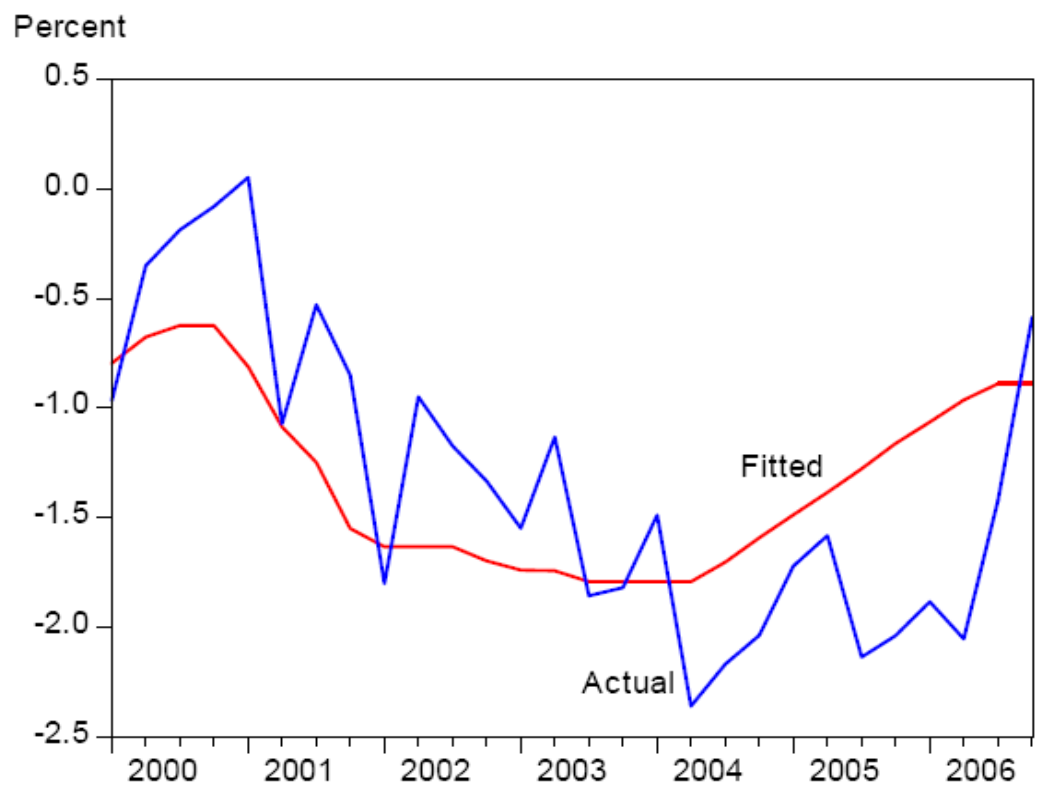

\section{Figure 5. Actual Deviations from a Euro Policy Rule and the Predicted (fitted) Values Based on the Federal Funds Rate}

\subsection{Monetary Interaction with the Subprime Mortgage Problem}

A sharp boom and bust in the housing markets would be expected to have had impacts on the financial markets as falling house prices lead to delinquencies and foreclosures. These effects were amplified by several complicating factors including the use of sub-prime mortgages, especially the adjustable rate variety which led to excessive risk taking. In the United States this was encouraged by government programs designed to promote home ownership, a worthwhile goal, but overdone in retrospect.

It is important to note, however, that the excessive risk taking and the low interest monetary policy decisions are connected. Evidence for this connection is shown in Figure 6 which plots housing price inflation along with foreclosure and delinquency rates on adjustable rate subprime mortgages. The figure shows the sharp increase in housing price inflation from 
mid 2003 to early 2006 and the subsequent decline. Observe how delinquency rates and foreclosure rates were inversely related to housing price inflation during this period. During the years of the rapidly rising housing prices, delinquency and foreclosure rates declined rapidly. The benefits of holding onto a house, perhaps working longer hours to make the payments, are higher when the price of the house is rising rapidly. When prices are falling, the incentives to do so are much less and turn negative if the price of the house falls below the value of the mortgage. Hence, delinquencies and foreclosures rise.

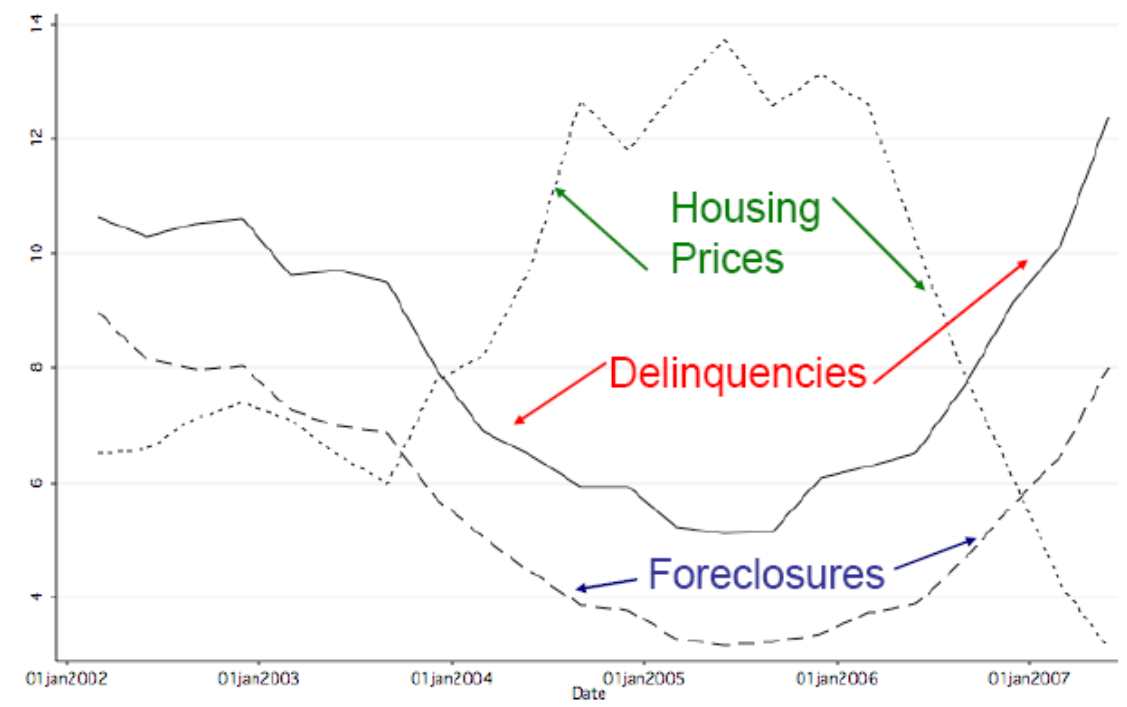

Figure 6. Housing Price Inflation and Subprime ARM Delinquencies and Foreclosures

Mortgage underwriting procedures are supposed to take account of the actual realizations of foreclosure rates and delinquency rates in cross section data. The procedures would therefore have been overly optimistic during the period when prices were rising unless they took account of the time series correlation in Figure 6. Thus there is an interaction between the monetary excesses and the risk-taking excesses. It is an illustration of how unintended things can happen 
when policy deviates from the norm. In this case, the rapidly rising housing prices and the resulting low delinquency rates likely threw the underwriting programs off track and misled many people.

\subsection{More Complications: Complex Securitization, Fannie, and Freddie}

A significant amplification of these problems occurred because the adjustable-rate subprime and other mortgages were packed into mortgage-backed securities of great complexity. The risk of these was underestimated by the rating agencies either because of a lack of competition, poor accountability, or most likely an inherent difficulty in assessing risk due to the complexity. It led to what might be called the "Queen of Spades problem” corresponding to the game of Hearts. In the game of Hearts you don't know where the Queen of Spades is; you don't want to get stuck with the Queen of Spades. Well, the Queens of Spades_-and there are many of them in this game - were the securities with the bad mortgages in them and people didn't know where they were. We didn't know which banks were holding them 14 months ago, and we still don't know where they are. This risk in the balance sheets of financial institutions has been at the heart of the financial crisis from the beginning.

In the United States there were other government actions at play here. The government sponsored agencies Fannie Mae and Freddie Mac were encouraged to expand and buy mortgage backed securities, including those formed with the risky sub-prime mortgages. While legislation, such as the Federal Housing Enterprise Regulatory Reform Act of 2005, was proposed to control these excesses, it was not passed into law. These actions of these agencies should be added to the list of government interventions that were part of the problem. 


\section{What Prolonged the Crisis?}

The financial crisis became acute on August 9 and 10, 2007 when the money market interest rates rose dramatically. Figure 7 illustrates this using a measure which has since become the focus of many studies. The measure is the spread between three-month Libor and the threemonth Overnight Index Swap (OIS). The OIS is a measure of what the markets expect the federal funds rate to be over the three-month period comparable to three month Libor.

Subtracting OIS from Libor effectively controls for expectations effects which are a factor in all term loans, including three-month Libor. The difference between Libor and OIS is thus due to things other than interest rates expectations, such as risk and liquidity effects.

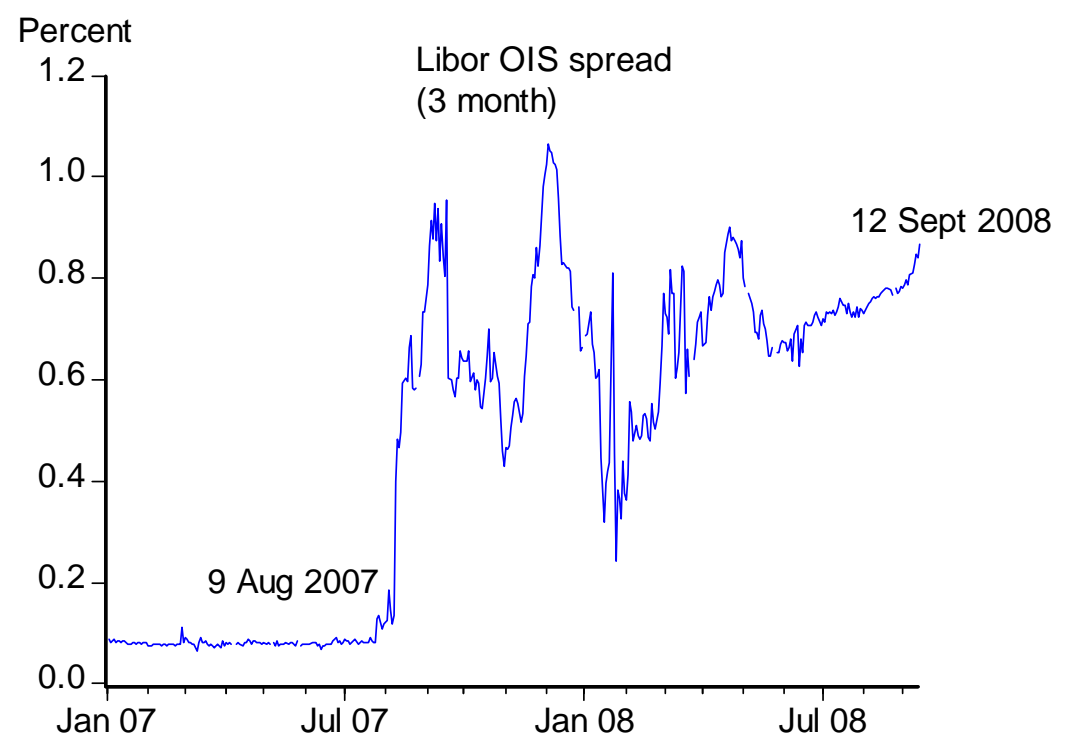

Figure 7. The Libor-OIS Spread During the First Year of the Crisis

If you look at the lower left of Figure 7 you see a spread of about 10 basis points. If you extended that further to the left, you would see a similarly steady level of about ten basis points. On August 9th and 10th of 2007 this spread jumped to unusually high levels and has remained 
high ever since. In our research [3] on this episode, John Williams and I called the event "A Black Swan in the Money Market,” because it appeared to be so unusual. Observe that Figure 7 focuses on the first year of the crisis. The worsening situation in September and October 2008 is covered in the next section.

In addition to being a measure of financial stress, the spread affects the transmission mechanism of monetary policy to the economy because trillions of dollars of loans and securities are indexed to Libor. An increase in the spread, holding the OIS constant, will increase the cost of such loans and have a contractionary effect on the economy. Bringing this spread down therefore became a major objective of monetary policy, as well as a measure of its success in dealing with the market turmoil.

\subsection{Diagnosing the Problem: Liquidity or Counterparty Risk?}

Diagnosing the reason for the increased spreads was essential, of course, for determining what type of policy response was necessary. If it was a liquidity problem then providing more liquidity by making discount window borrowing easier or opening new windows or facilities would be appropriate. But if the issue was counterparty risk then a direct focus on the quality and transparency of the bank’s balance sheets would be appropriate, either by requiring more transparency, dealing directly with the increasing number of mortgage defaults as housing prices fell, or looking for ways to bring more capital into the banks and other financial institutions.

In the fall of 2007 John Williams and I embarked on what we thought would be an interesting and possibly policy relevant research project [3] to examine the issue. We interviewed traders who deal in the interbank market and we looked for measures of counterparty risk. The idea that counterparty risk was the reason for the increased spreads made sense 
because it corresponded to the Queen of Spades theory and other reasons for uncertainty about banks' balance sheets. At the time however, many traders and monetary officials thought it was mainly a liquidity problem.

To assess the issue empirically, we looked for measures of risk in these markets to see if they were correlated with the spread. One good measure of risk is the difference between interest rates on unsecured and secured interbank loans of the same maturity. Examples of secured loans are government-backed Repos between banks. By subtracting the interest rate on Repos from Libor, you could get a measure of risk. Using regression methods, we then looked for the impact of this measure of risk on the Libor spread and showed that it could explain much of the variation in the spread. Other measures of risk gave the same results.

The results are illustrated in Figure 8 which shows the high correlation between the unsecured-secured spread and the Libor-OIS spread. There seemed to be little role for liquidity. These results suggested, therefore, that the market turmoil in the interbank market was not a liquidity problem of the kind that could be alleviated simply by central bank liquidity tools. Rather it was inherently a counterparty risk issue, which linked back to the underlying cause of the financial crisis. This was not a situation like the Great Depression where just printing money or providing liquidity was the solution; rather it was due to fundamental problems in the financial sector relating to risk. 


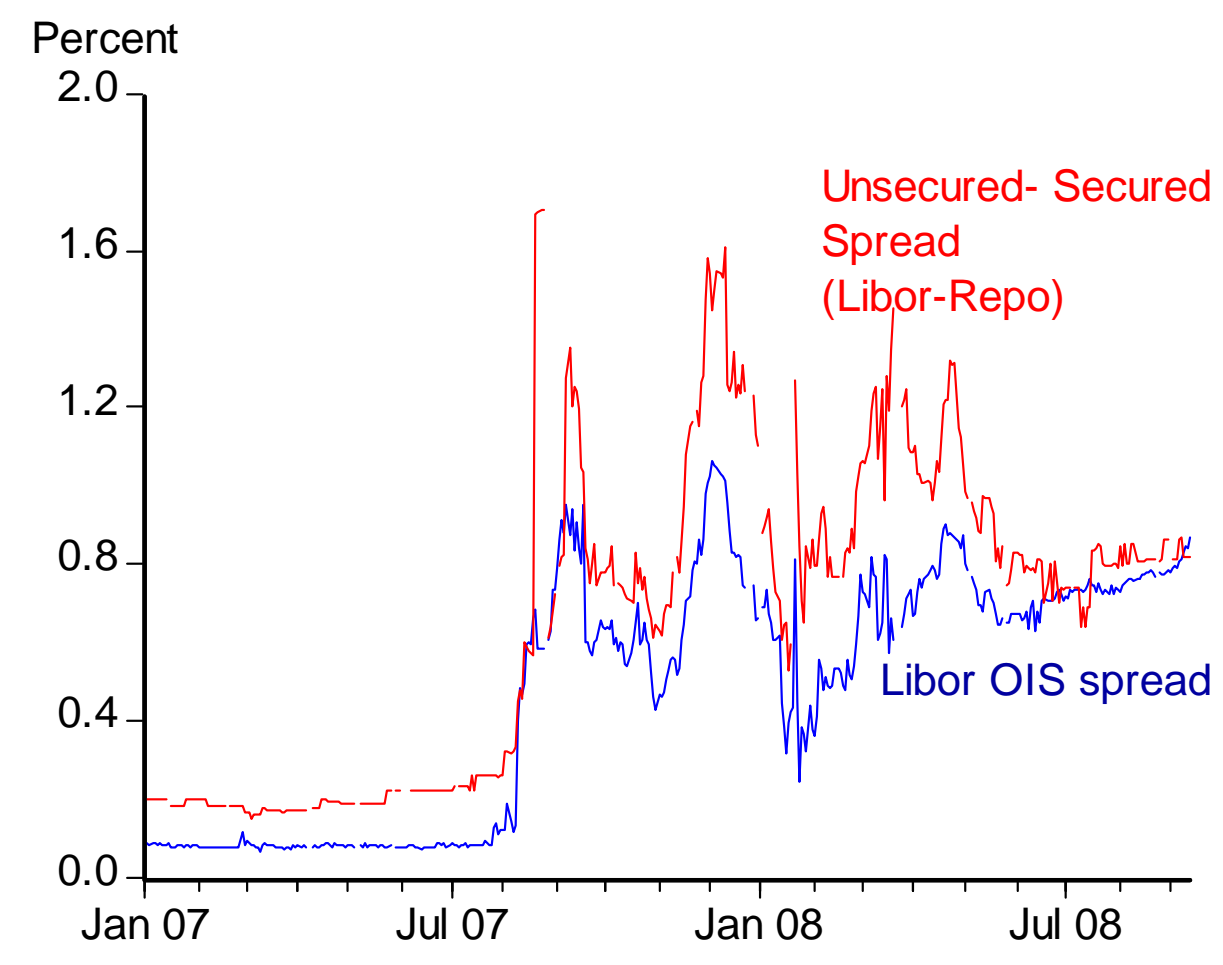

Figure 8. Counterparty Risk Explained Most of the Variation

But this was not the diagnosis that drove economic policy during this period. While it is difficult to determine the diagnosis of policy makers because their rationales for the decisions are not always explained clearly, it certainly appears that the increased spreads in the money markets were seen by the authorities as liquidity problems rather than risk. Accordingly, their early interventions focused mainly on policies other than those which would deal with the fundamental sources of the heightened risk. As a result, in my view, the crisis continued. 


\subsection{Three examples}

As evidence I provide three specific examples of the interventions that prolonged the crisis either because they did not address the problem or because they had unintended consequences.

\subsubsection{Term Auction Facility}

To make it easier for banks to borrow from the Fed, the term auction facility (TAF) was introduced in December 2007. With this new facility, banks could avoid going to the discount window; they could bid directly for funds from the Fed. Similar facilities were set up simultaneously at other central banks. The main aim of the TAF was to reduce the spreads in the money markets and thereby increase the flow of credit and lower interest rates. Figure 9, which is drawn from my paper with John Williams, shows the amount of funds taken up (on the right scale) along with Libor and OIS spread (on the left scale). Recall that this chart does not go beyond mid September 2008. 


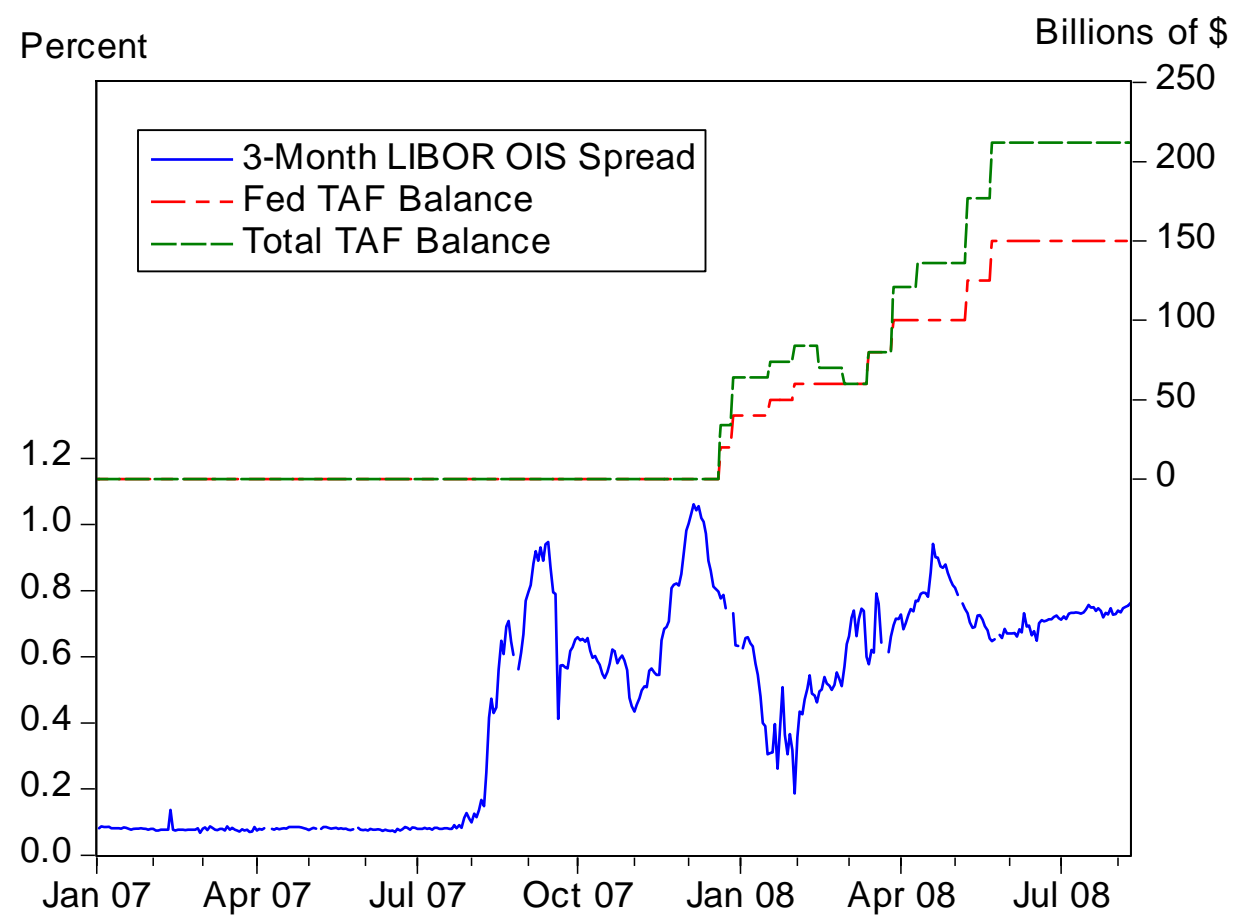

Figure 9. The Term Auction Facility Had Little Impact on the Spread

Soon after the introduction of the TAF in December 2007, the spread came down a bit and some policy makers suggested that it was working. But soon the spread rose again, and if you look at Figure 9, it is hard to see any effect on the spread during this whole period. This visual impression is confirmed with detailed regression analysis. The TAF did not seem to make much difference. If you think of the reason for the spread as counterparty risk as distinct from liquidity, this is not surprising.

\subsubsection{Temporary Cash Infusions}

Another early policy response was the Economic Stimulus Act of 2008 passed in February. The major part of this package was to send cash totaling over $\$ 100$ billion to 
individuals and families in the United States so they would have more to spend and thus jumpstart consumption and the economy. Most of the checks were sent in May, June, and July. While not a purely monetary action because the rebate was financed by borrowing rather than money creation, like the liquidity facilities it was not focused on the underlying causes of the crisis. Moreover, as would be predicted by the permanent income theory of consumption, people spent little if anything of the temporary rebate, and consumption was not jump-started as had been hoped. The evidence is in Figure 10, which is drawn from research reported in [4]. The top line shows how personal disposable income jumped at the time of the rebate. The lower line shows that personal consumption expenditures did not increase in a noticeable way. As with the earlier charts, formal statistical work shows that the rebates had no statistically significant increase in consumption.

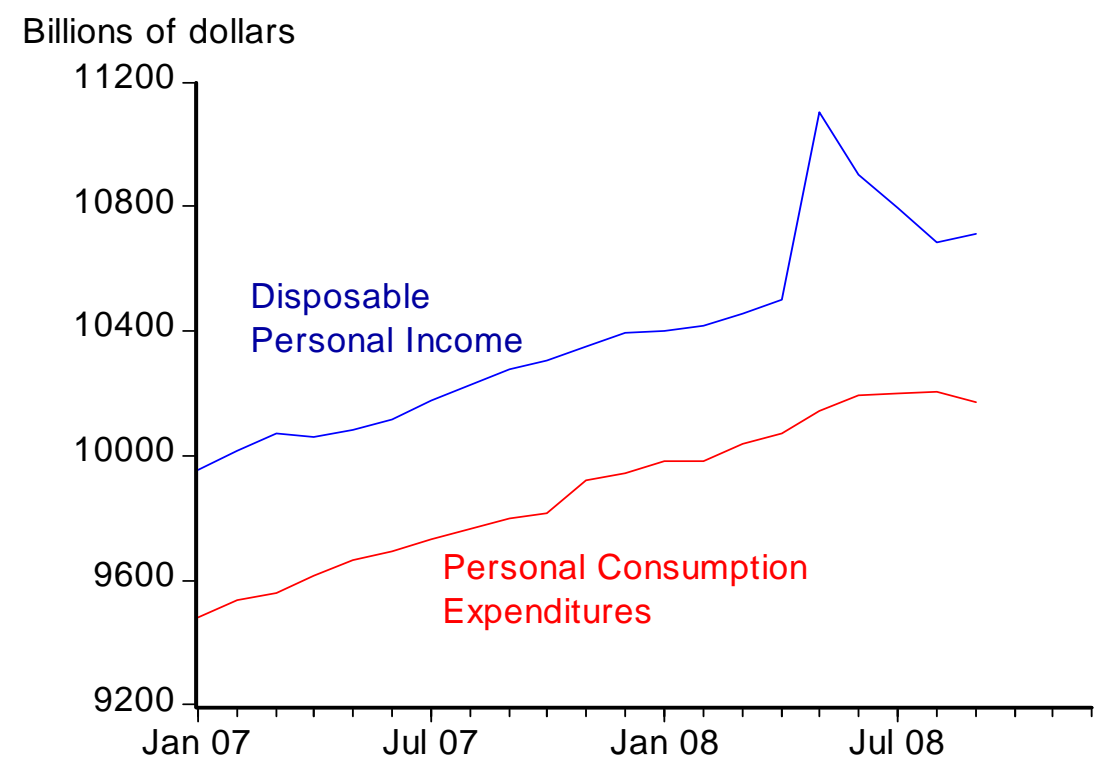

Figure 10. The Rebates Increased Income, But Not Consumption. (Monthly data, seasonally adjusted, annual rates). 


\subsubsection{The Initial Cuts in Interest Rates through April 2008}

A third policy response to the financial crisis was the sharp reduction in the federal funds rate in the first half year of the crisis. The federal funds rate target went from 5-1/4 percent when the crisis began in August 2007 to 2 percent in April 2008. The Taylor rule also called for a reduction in the interest rate during this early period, but not as sharp. Thus the reduction was more than would be called for using the historical relation stressed at the start of this paper, even adjusting for the Libor-OIS spread as I suggested [5] in a speech at the Federal Reserve Bank of San Francisco and in testimony at the House Financial Services Committee in February.

It is difficult to assess the full impact of this extra sharp easing, and more research is needed. The lower interest rates reduced the size of the re-set of adjustable rate mortgages and thereby was addressed to some of the fundamentals causing the crisis. Some of these effects would have occurred if the interest rate cuts were less aggressive.

The most noticeable effects at the time of the cut in the federal funds rate, however, were the sharp depreciation of the dollar and the very large rise in oil prices. During the first year of the financial crisis oil prices doubled from about \$70 per barrel in August 2007 to over \$140 in July 2008, before plummeting back down as expectations of world economic growth declined sharply. Figure 11 shows the close correlation between the federal funds rate and the price of oil during this period using monthly average data. The chart ends before the global slump in demand became evident and oil prices fell back. 


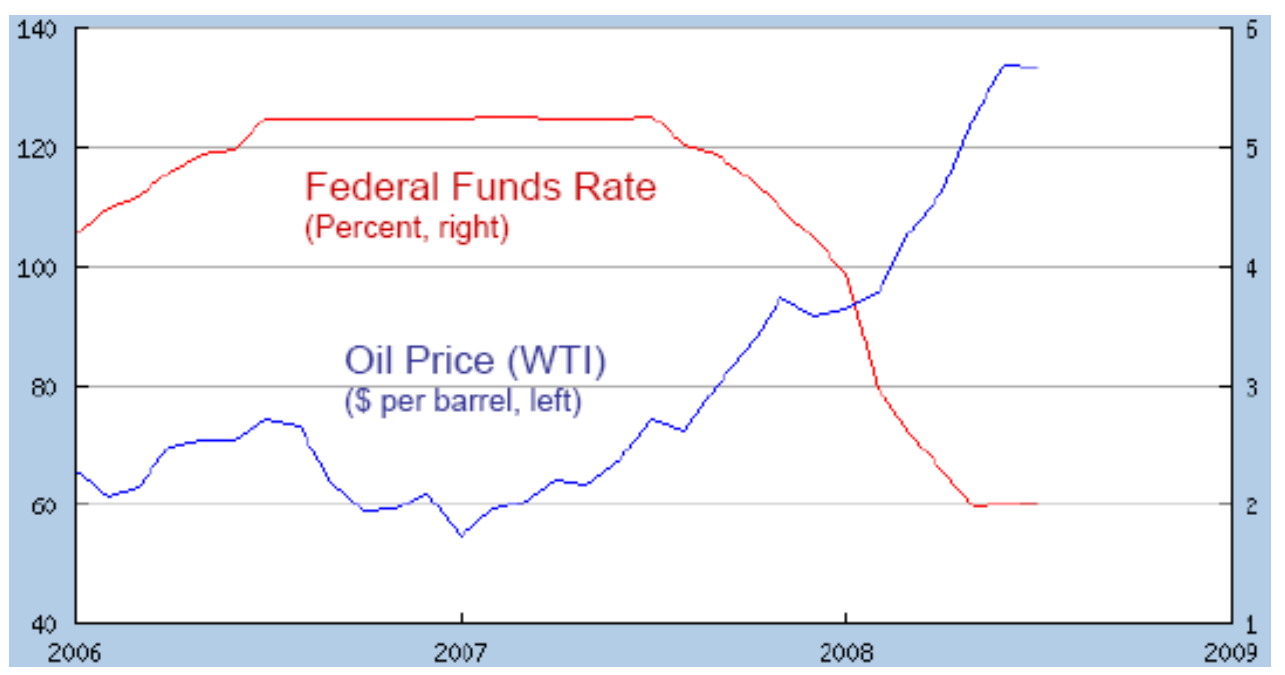

Figure 11. The Sharp Cut in Interest Rates Was Accompanied by a Rapid Increase in Oil Prices Through the First Year of the Crisis. (Last observation is July 2008)

When the federal funds rate was cut, oil prices broke out of the $\$ 60-\$ 70$ per barrel range and then rose rapidly throughout the first year of the financial crisis. Clearly this bout of high oil prices hit the economy hard as gasoline prices skyrocketed and automobile sales plummeted in the spring and summer of 2008. In my view, expressed in a paper [6] delivered at the Bank of Japan in May, this interest rate cut helped raise oil and other commodity prices and thereby prolonged the crisis.

Econometric evidence of the connection between interest rates and oil prices is found in existing empirical studies. For example, in early May 2008, the First Deputy Managing Director of the International Monetary Fund John Lipsky said: "Preliminary evidence suggests that low interest rates have a statistically significant impact on commodity prices, above and beyond the typical effect of increased demand. Exchange rate shifts also appear to influence commodity prices. For example, IMF estimates suggest that if the US dollar had remained at its 2002 peak 
through end-2007, oil prices would have been \$25 a barrel lower and non-fuel commodity prices 12 percent lower."4

When it became clear in the fall of 2008 that the world economy was turning down sharply, oil prices then returned to the $\$ 60-\$ 70$ range. But by this time the damage of the high oil prices had been done.

\section{Why Did the Crisis Worsen So Dramatically More Than a Year After It Began?}

Figure 12 shows, using the same Libor-OIS measure of tension in the financial markets as in Figure 7, how dramatically the financial crisis worsened in October 2008. Recall that in our research paper on the subject, John Williams and I called the jump in spreads in August 2007 “A Black Swan in the Money Market.” The October 2008 events were even more unusual. Not only was the crisis prolonged for more than a year, it worsened, according to this measure, by a factor of four. It became a serious credit crunch with large spillovers, seriously weakening an economy already suffering from the lingering impacts of the oil price bout and the housing bust. Notice the close correlation between our measure of counterparty risk and the Libor-OIS spread, which demonstrates convincingly that all along the problems in the market were related to risk rather than liquidity.

\footnotetext{
${ }^{4}$ See John P. Lipsky, “Commodity Prices and Global Inflation,” Council on Foreign Relations, New York City, May 8, 2008
} 


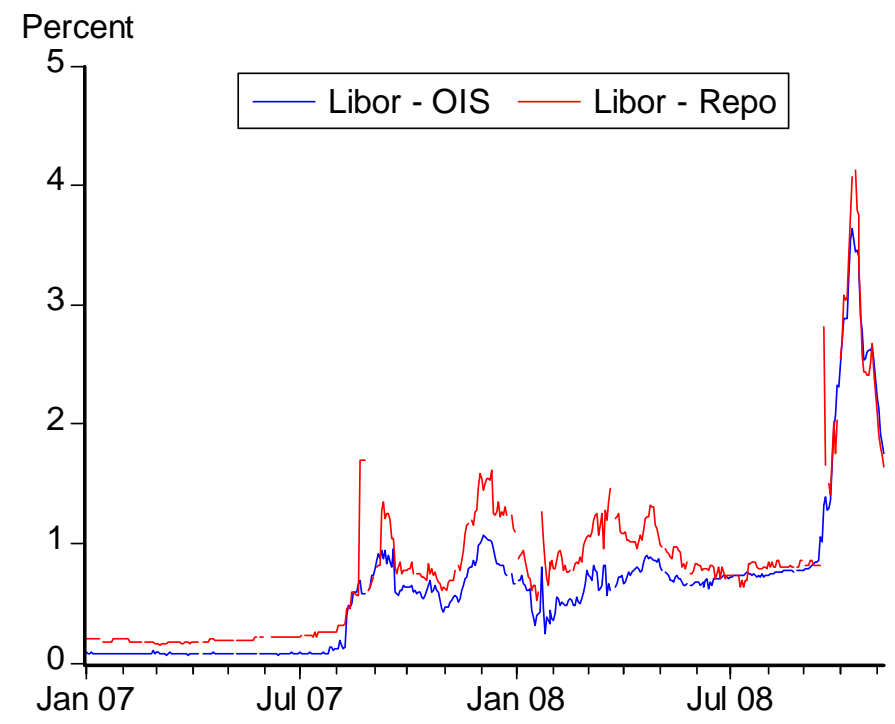

Figure 12. Evidence of the Crisis Worsening Dramatically Fourteen Months after It Began

\subsection{An Event Study}

Many commentators have argued that the reason for the worsening of the crisis was the decision by the U.S. government (more specifically the Treasury and the Federal Reserve) not to intervene to prevent the bankruptcy of Lehman Brothers over the weekend of September 13 and 14. It is difficult to bring rigorous empirical analysis to this important question, but it is important that researchers do so because future policy actions depend on the answer. Perhaps the best empirical analyses we can hope for at this time are "event studies” that look carefully at reactions in the financial markets to various decisions and events. Such an event study, summarized below, suggests that the answer is more complicated than the decision not to intervene to prevent the Lehman bankruptcy and, in my view, lies elsewhere.

Figure 13 focuses on a few key events from September 1 through mid October-the last few observations in Figure 12. Since mid October a host of new policy interventions have taken 
place-including implementation of the Troubled Asset Relief Program (TARP), guarantees by the FDIC, Federal Reserve support for the commercial paper market, similar actions in other countries—and conditions have improved somewhat as seen in the graph. But the question here is what led to the worsened conditions, which have so severely affected the economy and generated so many unprecedented clean-up actions.

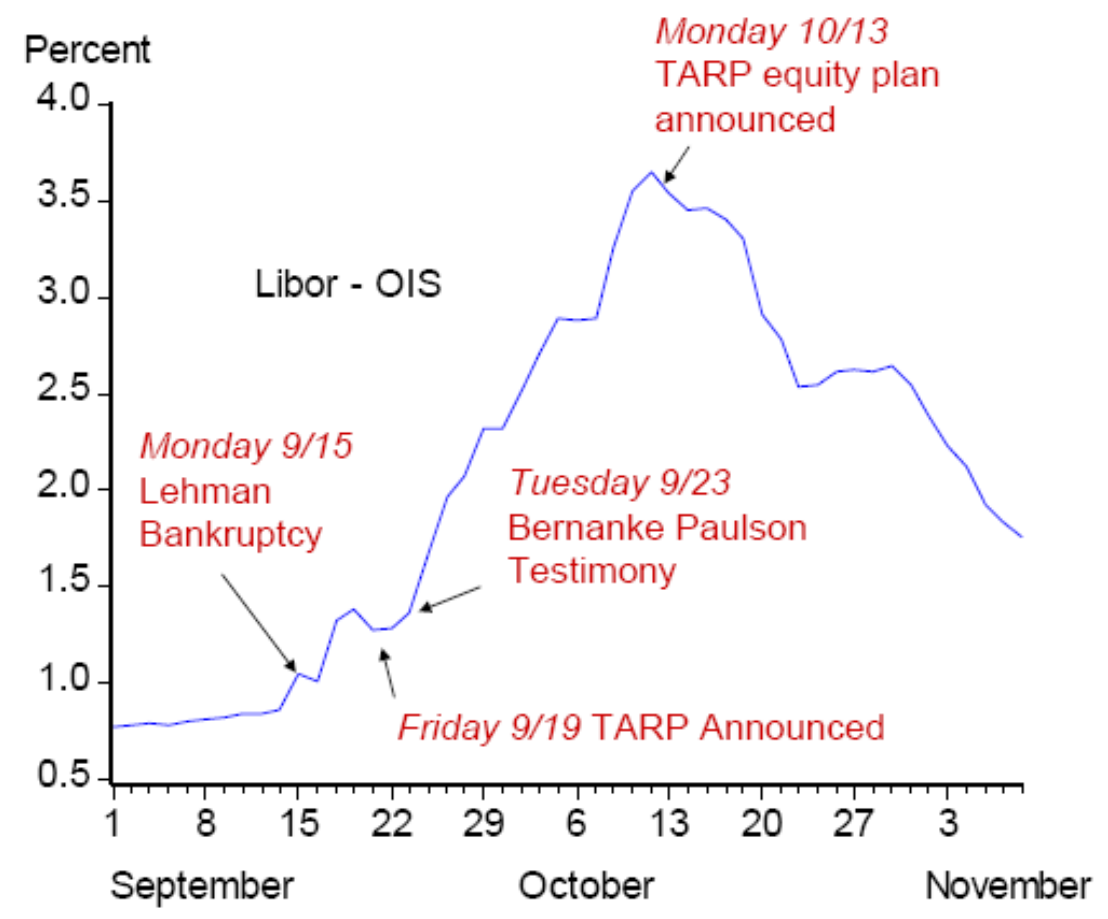

Figure 13. Event Study of the Dramatic Worsening of the Crisis

Recall that for the year previous to the events in Figure 13, the spread had been fluctuating in the 50 to 100 basis point range which was where it was through the first half of September 2008. You can see that the spread moved a bit on September 15th, which is the Monday after the weekend decisions not to intervene in Lehman Brothers. It then bounced back 
down a little bit on September 16 around the time of the AIG intervention. While the spread did rise during the week following the Lehman Brothers decision, it was not far out of line with the events of the previous year.

On Friday of that week the Treasury announced that it was going to propose a large rescue package, though the size and details weren't there yet. Over the weekend the package was put together and on Tuesday September 23, Federal Reserve Board Chairman Ben Bernanke and Treasury Secretary Henry Paulson testified at the Senate Banking Committee about the TARP, saying that it would be $\$ 700$ billion in size. They provided a 2-1/2 page draft of legislation with no mention of oversight and few restrictions on the use. They were questioned intensely in this testimony and the reaction was quite negative, judging by the large volume of critical mail received by many members of the United States Congress. As shown in Figure 13 it was following this testimony that one really begins to see the crises deepening, as measured by the relentless upward movement in Libor-OIS spread for the next three weeks. Things steadily deteriorated and the spread went through the roof to 3.5 per cent.

\subsection{The Lack of a Predictable Framework for Intervention}

The main message of Figure 13 is that identifying the decisions over the weekend of Sept 13 and 14 as the cause of the increased severity of the crisis is questionable. It was not until more than a week later that conditions deteriorated. Moreover, it is plausible that events around September 23 actually drove the market, including the realization by the public that the intervention plan had not been fully thought through and that conditions were much worse than many had been led to believe. At a minimum a great deal of uncertainty about what the government would do to aid financial institutions, and under what circumstances, was revealed 
and thereby added to business and investment decisions at that time. Such uncertainty would have driven up risk spreads in the interbank market and elsewhere. Some evidence of the uncertainty is found in a survey taken later (November 5) by the Securities Industry and Financial Markets Association (SIFMA); it showed that 94 percent of securities firms and banks found that the TARP lacked clarity about its operations.

The problem of uncertainty about the procedures or criteria for government intervention to prevent financial institutions from failing had existed since the time of the Bear Stearns intervention in March. The implication of that decision for future interventions was not made clear by policymakers. This lack of predictability about Treasury-Fed intervention policy and recognition of the harm it could do to markets likely increased in the fall of 2008 when the underlying uncertainty was revealed for all to see. What was the rational for intervening with Bear Stearns, and then not with Lehman, and then again with AIG? What would guide the operations of the TARP?

Worries about the lack of clarity were raised in many quarters. At a conference on The Future Role of Central Banking: The Urgent and Precedent-Setting Next Steps held on the Stanford campus in July to address the new interventions, I argued [7] that the U.S. Treasury and the Fed urgently needed to develop a new framework for exceptional access to government support for financial institutions. I made analogies to a reform put in place at the IMF in 2003 which clarified the circumstances under which the IMF would provide loans to countries experiencing crises. After these IMF reforms were put in place, the eight year emerging market crisis period that had begun in 1995 came to a close.

Analogously, a new exceptional access framework would describe the process that the U.S. and other governments would take when intervening and providing loans to an institution. 
It would work like the IMF's exceptional access framework (EAF) which indicated the procedures the IMF should take when providing loans to a country. The more policy-makers could articulate the rationale and the procedures the better.

\section{Conclusion}

In this paper I have provided empirical evidence that government actions and interventions caused, prolonged, and worsened the financial crisis. They caused it by deviating from historical precedents and principles for setting interest rates, which had worked well for 20 years. They prolonged it by misdiagnosing the problems in the bank credit markets and thereby responding inappropriately by focusing on liquidity rather than risk. They made it worse by providing support for certain financial institutions and their creditors but not others in an ad hoc way without a clear and understandable framework. While other factors were certainly at play, these government actions should be first on the list of answers to the question of what went wrong.

What are the implications of this analysis for the future? Most urgently it is important to reinstate or establish a set of principles to follow to prevent misguided actions and interventions in the future. Though policy is now in a massive clean-up mode, setting a path to get back to these principles now can be part of the clean-up, including

- Returning to the set of principles for setting interest rates that worked well during the Great Moderation.

- Basing any future government interventions on a clearly stated diagnosis of the problem and a rationale for the interventions. 
- Creating a predictable exceptional access framework for providing financial assistance to existing financial institutions. The example of how the International Monetary Fund set up an exceptional access framework to guide its lending decisions to emerging market countries is a good one to follow.

Some of these reforms require a rethinking of the international financial architecture and others are purely domestic. For example, to keep policy interest rates on track in a globalized economy it would help to introduce the notion of a global inflation target [3]. This would help prevent rapid cuts in interest rates in one country if they perversely affect decisions in other countries. Policy makers could then discuss global goals for inflation and the impact that one central bank might have on global inflation. In contrast, developing exceptional access frameworks for central banks and finance ministries could be done in each country without a global structure. Similarly setting controls on leveraging at the financial institutions could be done in each country.

Finally I want to stress that the research presented in this paper must be considered preliminary. We are still in the middle of the crisis and more data need to be collected and analyzed. There are and will continue to be differences of opinion. Carefully documented empirical research is needed for sorting out these differences. We should be basing our policy evaluations and conclusions on empirical analyses not ideological, personal, political, or partisan grounds. 


\section{Summary of Empirical Research Projects}

The empirical research projects that I integrated and summarized for this paper are found below. [1] “Housing and Monetary Policy,” in Housing, Housing Finance, and Monetary Policy Federal Reserve Bank of Kansas City. This paper reported on research completed in the summer of 2007 before the August flare up in the financial markets. It focuses on the relationship between monetary policy and the housing boom. It was delivered at a policy panel at the annual Jackson Hole conference, August 30 - September 1, 2007.

[2] “Globalization and Monetary Policy: Missions Impossible,” in Mark Gertler and Jordi Gali (Eds.) The International Dimensions of Monetary Policy, National Bureau of Economic Research. This paper summarized research on globalization and monetary policy pointing to the potential problem caused by central banks following each other either directly or indirectly. This provided on explanation for why several central banks held interest rates too low in the 20022004 period. The paper was prepared for a talk at an NBER conference in Girona, Spain on June 11, 2007.

[3] “A Black Swan in the Money Market,” with John C. Williams, American Economic Journal Macroeconomics, January 2009. This is the final revision of research we started in the fall of 2007 on whether the unusual jump in interbank lending rates in August 2007 was caused by liquidity problems or counterparty risk. A working paper (No. 2008-04) with the same title was issued by the Federal Reserve Bank of San Francisco in April and another working paper, “Further Results on a Black Swan in the Money Market” was issued in May by the Stanford Institute for Economic Policy Research.

[4] “The State of the Economy and Principles for Fiscal Stimulus," Testimony before the Senate Budget Committee, November 19, 2008. This testimony reports on a project to estimate the 
impact of the tax rebates of 2008 on the economy, with more formal econometric evidence in a paper prepared for the American Economic Association meeting in San Francisco, January 2009 [5] "The Costs and Benefits of Deviating from the Systematic Component of Monetary Policy," keynote address at the Federal Reserve Bank of San Francisco conference on Monetary Policy and Asset Markets, February 22, 2008 and "Monetary Policy and the State of the Economy," testimony before the House Financial Services Committee, February 26, 2008. These items examined whether monetary policy rules should be adjusted for the increased spread in the money markets.

[6] "The Way Back to Stability and Growth in the Global Economy,” Institute for Monetary and Economic Studies, Discussion Paper 2008-E-14, was presented as the inaugural Mayekawa lecture at the Bank of Japan in May 2008. It discussed the impact of the sharp monetary easing on oil and other commodity prices and proposed the idea of a global inflation target as a means of preventing central banks' interest rate decisions to spread to other central banks. [7] "Toward a New Framework for Exceptional Access," is a presentation for the policy workshop on The Future Role of Central Banking Policy: Urgent and Precedent-Setting Next Steps, held at Stanford University on July 22, 2008. This presentation laid out the case for developing a more systematic approach to Fed's interventions and bailouts of financial institutions or their creditors. It followed the Bear Stearns intervention but was before the Lehman bankruptcy. 